\title{
Bacteriological Analysis of Drinking Water by MPN Method in a Tertiary Care Hospital and Adjoining Area Western Up, India
}

\author{
Deepesh Kumar*1 Shurutikirti Malik², Molly Madan ${ }^{3}$, Anita Pandey ${ }^{4}$, \\ Ashish K. Asthana 5 . \\ ${ }^{1}$ M.Sc.Student, Deptt. Of Microbiology, Subharti Medical College, MEERUT, U.P., INDIA. \\ ${ }^{2}$ M.Sc.Student, Deptt. Of Microbiology, Subharti Medical College, MEERUT, U.P., INDIA. \\ ${ }^{3}$ Professor \& Head, Deptt. Of Microbiology, Subharti Medical College, MEERUT, U.P., INDIA. \\ ${ }^{4}$ Professor, Deptt. Of Microbiology, Subharti Medical College, MEERUT, U.P., INDIA. \\ ${ }^{5}$ Asst. Professor, Deptt. Of Microbiology, Subharti Medical College, MEERUT, U.P., INDIA.
}

\begin{abstract}
A total of 116 drinking water samples were collected aseptically in sterilized container from different sources. over a period of nine month September to May 2012.Most probable number (MPN) test was done to detect the coliforms in drinking water samples. The MPN number was very high $\geq 180)$ of positive water samples. Analysis was performed using culture and biochemical methods. The organism was identified as Escherichia coli (28\%), Klebsiella sp. (15\%) and Pseudomonas sp. (25\%) in total positive samples. To conclude, bacteriological assessment of all water sources for drinking should be planned and conducted on regular basis.
\end{abstract}

Key Words: Drinking water sample, MPN count, Coliforms

\section{Introduction}

Water is the most abundant chemical in the human body and plays a central role in the regulation of nutrient transport, toxic waste removal, thermal regulation and digestion, organ functioning and metabolic activities. However, if water is fecally polluted it spreads diseases in consumers to a great number of people ${ }^{1}$.

World health organization estimated in 2000 assessment that there are four billion cases of diarrhea each year in addition to millions to other cases of illness associated with the lack of access of clean water ${ }^{2}$. It is well established that infectious diseases are transmitted primarily through water supplies contaminated with human and animal excreta particularly faeces ${ }^{3}$.Out breaks of water borne diseases continue to occur throughout the world but are especially serious in developing countries ${ }^{4,5}$.

The human pathogens that present serious risk of disease whenever present in drinking water include Salmonella species, Shigella species, pathogenic Escherichia coli, Vibrio cholerae, Yersinia entercolitica, Campylobacter species, various viruses such as Hepatitis A, Hepatitis E, Rota virus and parasites such as Entamoeba histolytica and Giardia species and so on ${ }^{5-7}$.

Public and environmental health protection requires safe drinking water, which means that it must be free of pathogenic bacteria.

\section{1- What are coliforms?}

The coliform group includes a broad diversity in terms of genus and species, whether or not they belong to the Enterobacteriaceae family. Most definitions of coliforms are essentially based on common biochemical characteristics. In Standard Methods for the examination of water and wastewater (Part 9221 and 9222; APHA et al., 1998), coliform group members are described as-

1. All aerobic and facultative anaerobic, Gram negative, non spore forming, rod shaped bacteria that ferment lactose with gas and acid formation within $48 \mathrm{~h}$ at $35^{\circ} \mathrm{C}$ (multiple-tube fermentation technique; Section 3.1) or 2.All aerobic and many facultative anaerobic, Gram negative, non spore forming ,rod shaped bacteria that develop a red colony with a metallic sheen within $24 \mathrm{~h}$ at $35^{\circ} \mathrm{C}$ on an Endo type medium containing lactose (membrane filter technique; Section 3.2).

The definition of members of the coliform group has recently been extended to include other characteristics, such as $\beta$-D galactosidase positive reactions (Part 9223; APHA et al., 1998) (enzyme substrateA.Rompre 'et al. / Journal of Microbiological Methods 49 (2002) 31-5432test, Section 4.2).

The search for $\beta$-galactosidase positive and $\beta$-galactoside permease positive organisms also permits a confirmation step for lactose fermentation, when the multiple tube fermentation technique is used. The cytochrome-oxidase test is also used as a confirmation test to eliminate some bacteria of the Aeromonas or Pseudomonas genera that would ferment lactose. The definition of coliform bacteria differs slightly depending 
on the country or on the organization in charge of the microbiological monitoring regulations. In Canada, the definition is the same as in the US, and differs in some European countries. For example, the French Standardization Association (NFT90-413 and NFT90-414; AFNOR, 1990), which can be considered as a representative model for European legislation, defines total coliforms (TC) as rod shaped, non spore forming, Gram negative, oxidase negative, aerobic or facultative anaerobic bacteria that are able to grow in the presence of bile salts or other replacement surface active agents having an analogous growth inhibitory effect and that ferment lactose with gas and acid (or aldehyde) production within $48 \mathrm{~h}$ at $37 \pm 1^{\circ} \mathrm{C}$. AFNOR (1990) goes further by defining other coliform groups, including the thermotolerant coliforms (also called fecal coliforms, FC) and, more specifically, E. coli, thermotolerant coliforms have the same fermentation properties as total coliforms (TC) but at a temperature of $44 \pm 0.5{ }^{\circ} \mathrm{C}$.

Escherichia coli is a thermotolerant coliform which, among other things, produces indole from tryptophane at a temperature of $44 \pm 0.5{ }^{\circ} \mathrm{C}$, gives a positive methyl red test result, is unable to produce acetylmethyl carbinol and does not use citrate as its sole carbon source. Escherichia coli is the most common coliform among the intestinal flora of warm-blooded animals and its presence might be principally associated with fecal contamination. No Escherichia coli are therefore allowed in drinking water.

\section{2-Multiple-tube fermentation technique-}

The technique of enumerating coliforms by means of multiple-tube fermentation (MTF) has been used for over 80 years as a water quality monitoring method. The method consists of inoculating a series of tubes with appropriate decimal dilutions of the water sample. Principle:Fermentation tubes (other suitable vessels containing lactose broth (MacConkey) are inoculated with measured volumes of water samples; the coliform bacteria present in the water sample multiply and are detected by formation of acid and gas. From the number with a positive reaction, the most probable number (MPN) of bacteria present in the original water sample can be determined statistically.

The present study was designed to detect the coliforms bacteria in water samples and to determine the water supply system being operated correctly and safe water for drinking or food preparation.

\section{Materials And Methods}

A total of 116 drinking water samples were collected from each source according WHO guidelines for drinking water quality assessment ${ }^{8}$, over a period of nine month September to May 2012.

\subsection{Sample collection-}

About 200ml water samples from Government hand pump, water cooler and Municipal tap water were collected, labeled and transported to the laboratory for bacteriological analysis.

\subsection{Bacteriological analysis:}

Bacteriological analysis was carried out for indicator organisms i.e. total and fecal coliform (E.coli) by most probable number (MPN) method ${ }^{9,10 .}$.Ten tubes of MacConkeys broth (Hi media Pvt. Ltd Mumbai) arranged in two rows with a $100 \mathrm{ml}$ blood culture bottle. First row containing $10 \mathrm{ml}$ double strength MacConkeys broth was inoculated with $10 \mathrm{ml}$ of water sample and $50 \mathrm{ml}$ double strength MacConky broth was inoculated with $50 \mathrm{ml}$ of water sample. Second row containing $1 \mathrm{ml}$ single strength MacConkeys broth medium was inoculated with $1 \mathrm{ml}$ water sample respectively. Were incubated in an incubator at $44^{\circ} \mathrm{C}$ for $24 \mathrm{~h}$. After incubation, the number of bottles in which lactose fermentation with acid and gas production has occurred was counted. Finally, by referring to probability table (Macrady table-2) the MPN of coliform in $100 \mathrm{ml}$ water sample was been estimated (Cheesbrough, 2006).

Analysis is usually performed using culture and biochemical test also.

\section{Result and observation}

A total of 116 drinking water samples were tested by MPN method. Out of which, Total drinking water sample collected from Municipal Tap Water $=58(50 \%)$.

Total drinking water sample collected from Government Hand Pump $=32(28 \%)$.

Total drinking water sample collected from Water cooler $=26(22 \%)$. 


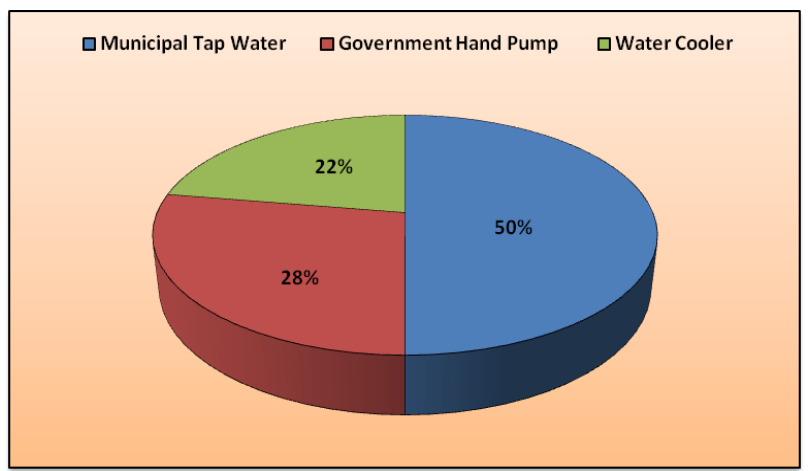

Figure. (1): Percentage Wise Distribution of Drinking Water Sample

After determinant of MPN number of positive sample, for organism identification do the culture \& biochemical test.

\subsection{Culture:}

From the $1 \mathrm{ml}$ tube (single strength) of positive test, a loop full specimen was taken and streaked into the MacConkey agar plate and incubate at $37{ }^{\circ} \mathrm{C}$ overnight.

\subsection{Interpretation:}

A mixed growth of either dry lactose fermenting, mucoid lactose fermenting and non-lactose fermenting growth appeared after the incubation (figure.2).

For Specification, the colonies were subcultured on other individual MacConkey agar plate from primary plate and incubate at $37^{\circ} \mathrm{C}$ overnight.

After the incubation a pure,heavy growth was on MacConkey agar plate (figure. 3,4\&5).

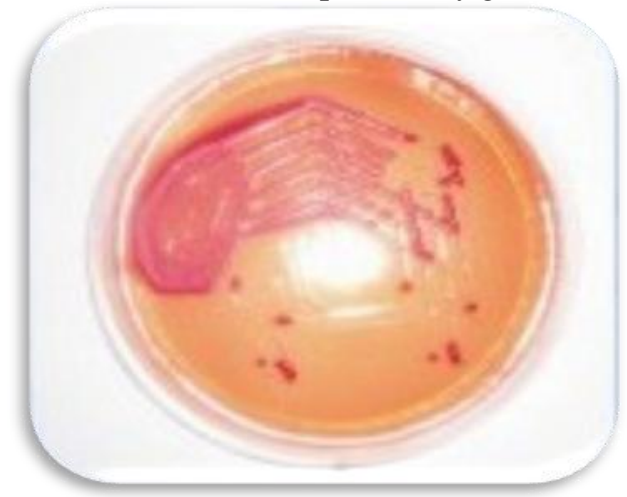

(Figure. 2)

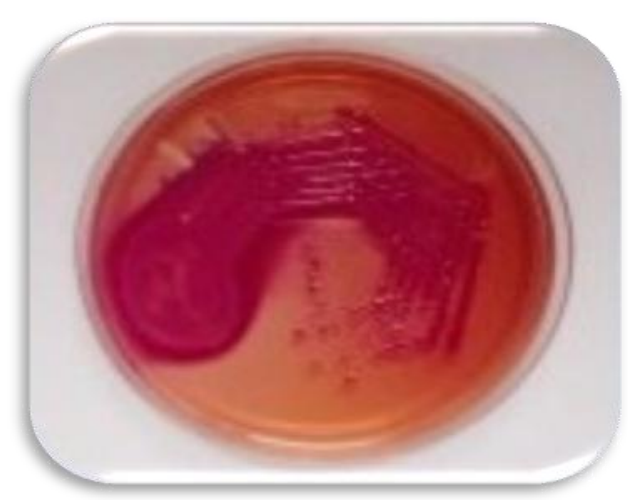

(Figure. 4)

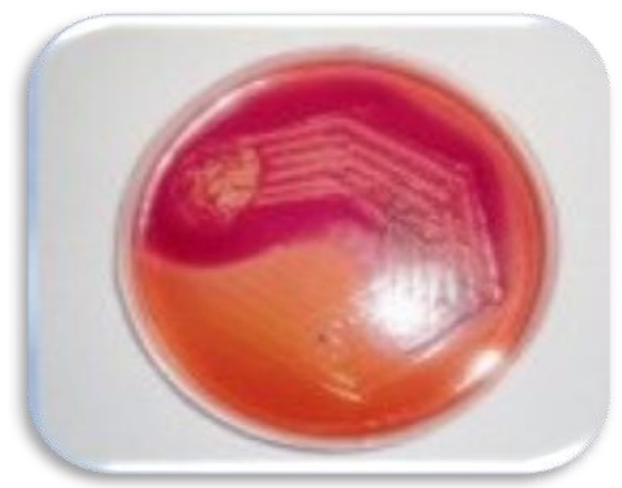

(Figure. 3)

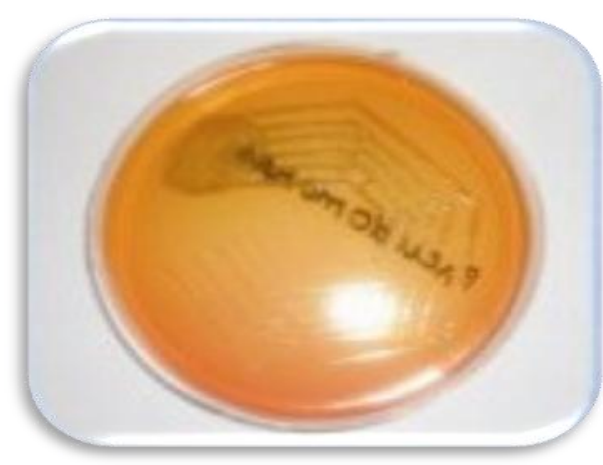

(Figure. 5) 
3.3 Biochemical Test:

For species identification the biochemical (IMViC) test as per WHO guideline was performed.

Table: 1 - Biochemical characterization.

\begin{tabular}{|c|c|c|c|c|c|}
\hline Organism & MR & VP & Indole & Urease & Citrate \\
\hline Escherichia coli & + & - & + & - & - \\
\hline Klebsiella & + & - & - & + & + \\
\hline Pseudomonas sp. & - & - & - & - & + \\
\hline
\end{tabular}

VP: Voges-Proskauer, MR: Methyl Red.

TABLE: 2 - Profile of Positive Sample ( $\mathrm{n}=116)$

\begin{tabular}{|l|c|c|c|c|}
\hline Source of Water & $\begin{array}{c}\text { Municipal } \\
\text { Tap } \\
\text { Water }\end{array}$ & $\begin{array}{c}\text { Municipal } \\
\text { Hand } \\
\text { Pump }\end{array}$ & $\begin{array}{c}\text { Water } \\
\text { Cooler }\end{array}$ & Total No. \\
\cline { 1 - 4 } Positivity & 58 & 32 & 26 & 116 \\
\hline Organism & 20 & - & 1 & 21 \\
\hline Escherichia coli & 8 & - & 1 & 9 \\
\hline Klebsiella Sp. & - & 5 & 15 & 20 \\
\hline Pseudomonas Sp. & 12 & - & 1 & 13 \\
\hline Mix Sample & & & & \\
\hline
\end{tabular}

TABLE: 3 - Profile of Mix Sample (n=13) with reference to sample no.

\begin{tabular}{|c|c|c|c|c|}
\hline \multirow{2}{*}{$\begin{array}{c}\text { No. of } \\
\text { Sample }\end{array}$} & $\begin{array}{c}\text { Escherichia coli, } \\
\text { Klebsiella Sp., } \\
\text { Pseudomonas Sp. }\end{array}$ & $\begin{array}{c}\text { Escherichia } \\
\text { coli, Klebsiella } \\
\text { Sp. }\end{array}$ & $\begin{array}{c}\text { Escherichia } \\
\text { coli, } \\
\text { Pseudomonas } \\
\text { Sp. }\end{array}$ & $\begin{array}{c}\text { Klebsiella Sp., } \\
\text { Pseudomonas } \\
\text { Sp. }\end{array}$ \\
\hline $\mathbf{3}$ & + & - & - & - \\
\hline $\mathbf{5}$ & - & - & + & - \\
\hline 4 & - & + & - & - \\
\hline 1 & - & - & - & + \\
\hline
\end{tabular}

TABLE: 4 - Profile of total positive sample ( $\mathrm{n}=116)$

\begin{tabular}{|c|c|c|c|c|c|}
\hline \multirow{2}{*}{$\begin{array}{c}\text { Source of water } \\
\text { sample }\end{array}$} & \multirow{2}{*}{$\begin{array}{c}\text { No. of Sample } \\
\text { collected }\end{array}$} & \multirow{2}{*}{$\begin{array}{c}\text { No. of Unsatisfactory } \\
\text { sample (\%) }\end{array}$} & \multicolumn{3}{|c|}{ Organism grown } \\
\cline { 4 - 6 } & & $\begin{array}{c}\text { Escherichia } \\
\text { coli }\end{array}$ & $\begin{array}{c}\text { Pseudomonas } \\
\text { Sp. }\end{array}$ & $\begin{array}{c}\text { Klebsiella } \\
\text { Sp. }\end{array}$ \\
\hline $\begin{array}{c}\text { Municipal Tap } \\
\text { Water }\end{array}$ & $\begin{array}{c}58 \\
(50 \%)\end{array}$ & $\begin{array}{c}40 \\
(69 \%)\end{array}$ & 32 & 8 & 15 \\
\hline $\begin{array}{c}\text { Government } \\
\text { Hand Pump }\end{array}$ & $\begin{array}{c}32 \\
(27.59 \%)\end{array}$ & $\begin{array}{c}5 \\
(15.62 \%)\end{array}$ & - & 5 & - \\
\hline Water Cooler & $\begin{array}{c}26 \\
(22.42 \%)\end{array}$ & $\begin{array}{c}18 \\
(70 \%)\end{array}$ & 1 & 16 & 2 \\
\hline Total & 116 & $\begin{array}{c}63 \\
(54.31 \%)\end{array}$ & $\begin{array}{c}33 \\
(28.44 \%)\end{array}$ & $\begin{array}{c}29 \\
(25 \%)\end{array}$ & $\begin{array}{c}17 \\
(14.65 \%)\end{array}$ \\
\hline
\end{tabular}


Figure.(6)- Percentage wise distribution of identifed organism (Bar Graph).

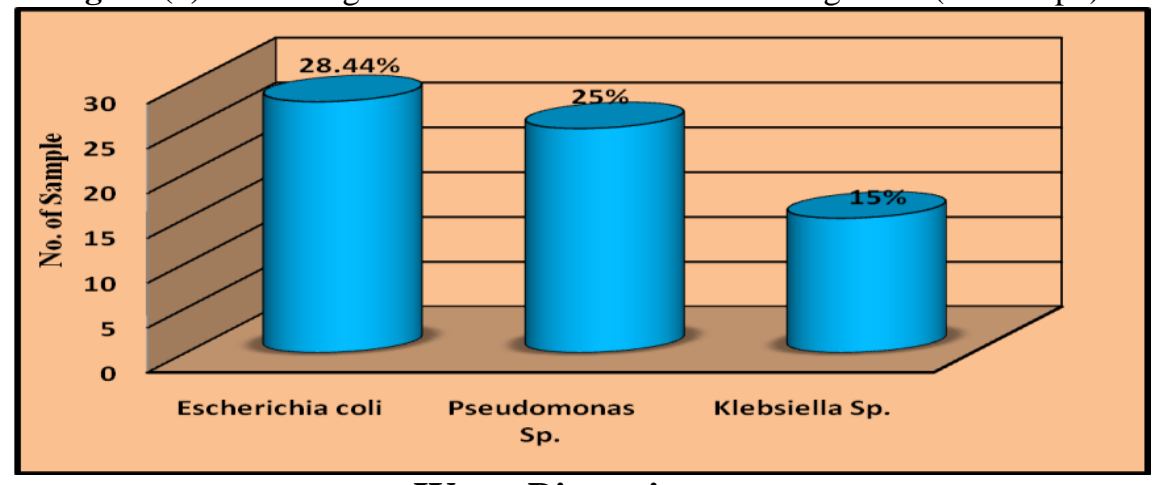

IV. Discussion

Much of the ill health which affects humanity, especially in developing countries can be traced to lack of safe and whole water supply. There can be no state of positive health and well being without safe water. Since water is vital for our life we expect it to be clean and safe. Even water that appears clear may not necessarily be safe or acceptable. The water intended for human consumption must be free of pathogenic and chemical agents, pleasant to taste and usable for domestic purposes since water is the most important potential source of infectious diseases So water purification is the most important potential available for ensuring public health $^{11}$

The survey report also revealed that every year several deaths particularly among children occurred due to water-born disease ${ }^{11}$.

In this study, MPN of coliform in case of water sample collected form municipal tap water was estimated to be very high $(\geq 180)$ and in case of water from water cooler, it was 90 , not portable, no coliform was detected from government hand pump supply for drinking.

Biochemical properties of bacteria clearly revealed the presence of Escherichia coli, Pseudomonas aeruginosa and Klebsiella Sp.in the water samples collected from municipal tap water and deep boring hand pump (table.2). According to Central Pollution Control Board India, total coliform organism MPN/100 ml shall be 50 or less in drinking water source ${ }^{12}$.

In developing world, especially in remote rural areas and industrial areas. Over 3 million deaths per year are attributed to water-bone diarrhoeal diseases, especially among infants and young children in poor communities (Davies-Colley et al, 2001).

The consumption of drinking water contaminated with pathogenic microbes of faecal origin is a significant risk to human health.

\section{To conclude,}

\section{Conclusion}

We would like to recommend the proper sanitary survey, design and implementation of water and sanitation projects; regular disinfections, maintenances and supervisions of water sources and regular bacteriological assessment of all water sources for drinking should be planned and conducted.

1. The Government hand pump water is safe for drinking, bathing and food preparation as compared to municipal tap water and water cooler.

2. The water cooler revealed the high number of Pseudomonas sp. means required the proper maintenance by change the filter and washing the filter time to time as per guidelines.

3. The MPN number method is reliable and effective but time consuming to perform; use for all type of water.

4. For ensuring safe and potable water supply, water should pass through three stages - storage, filtration and disinfection, storage removes $90-95 \%$ of the physical impurities by mechanism of suspension. It also allows penetration of light which resulting oxidation of organic matter by aerobic bacteria, thus decreasing free ammonia content of water.

5. Filtration is second stage of water purification which results in $98-99 \%$ drop in bacterial count apart from other impurities.

6. Disinfection is final stage of purification which results in destroying all pathogenic organisms left after storage and filtration.

7. All the stages are required in series for purification of water, Even if one stage is bypass. The water may not be rendered fit for drinking purposes. 


\section{Acknowledgement:}

The authors are grateful to the Prncipal,Dr. A.K.Asthana, Subharti Medical College, MEERUT,U.P., INDIA for giving permission to conduct the study.

\section{References;}

[1]. Nakade D.B., Assessment of bacteriological quality of water in Kolhapur city of Maharashtra,India.Int. Res.j.Enviromental Sci. ISSSN 2319-1414 vol.2 (2), 63-65, February 2013.

[2]. WHO, 2000 global water supply and sanitation assessment 2000 report.

[3]. WHO, guidelines for drinking water quality. Vol.1, Geneva, World Health Organisation. 1993, pp. 1- 29.

[4]. Manja KS, Maurva MS, Ran KM. A simple field test for the detection of faecal pollution in drinking water. Bull. WHO., 1982;60:797-801.

[5]. Emde KME, Mao H, Finch GR. Detection ad occurrence of water borne bacterial and viral pathogens. Water Environ. Ret, 1992:64:641-47.

[6]. Geldreich EL. Water borne pathogens invasions: A case for water quality protection in distribution. Proceedings of American Water Works Association. Water Quality Technology Conference, 1992: pp. 1-18.

[7]. Joklik WK, Willett HP, Amos DB, ct al, Ziusser Microbiology. 20th Ed., Norwalk; Appleton and Lange, 1992, pp. 393-400,

[8]. Guideline manual for drinking water quality monitoring and assessment: 2 nd edition.

[9]. Britton L.J., Greeson P.E., Methods for collection and analysis of aquatic biological and microbiological samples; US Geological survey techniques of water-resources investigations, book 5, chap., A4, 363-403 (1987) ..

[10]. American Public Health Association (APHA,1998), and Water Pollution Control Federation, Standard methods for the examination of water and waste water 20 th ed, Washington D.C, (1998).

[11]. S. Goel,R.Sood,S.R Mazta, P. Bansal \& A.gupta: Bacteriological quality of water sample of a tertiary care medical campus in North western Himalayan region of India .The Internet J. of third world med.2007,vol.5,No.1

[12]. P.R.Battu,M.S.Reddy:Bacteriological Examination of drinking water with refrence to coloiforms in Jeedimetla, Hydrabad,India.Afr.J. of Biotechnology Vol.8(20),pp 5506-5507.

[13]. WHO, 2000 global water supply and sanitation assessment 2000 report.

[14]. WHO (1997) Basic Environmental Health, Geneva.

[15]. Hunter PR. Water borne disease; epidemiology, Chichester; willey, 1997 Tillet HE. Most Probable Number organism, revised table of multiple tube methods, Epidemiology and disease99:471-76.

[16]. Mackie TJ, McCartney JE. Practical medical Microbiology, Churchill Livingstone (14 ${ }^{\text {th }}$ edition) WHO (1993) guideline for drinking water quality vol 12; 2nd edition.

[17]. Guideline manual for drinking water quality monitoring and assessment: $2^{\text {nd }}$ edition.

[18]. APHA (1998), standard Methods for examination of water and water waste $20^{\text {th }}$ ed; American Public Health Association, American Water works Association, Water Environmental Federation, Washinton, D.C.

[19]. Guidelines for drinking water quality: Volume 1 Recommendation, $2^{\text {nd }}$ edition. WHO Geneva. 1993. ISBN 9241544600.

[20]. Guidelines for drinking water quality: Volume 11 Health and other supporting criteria, $2^{\text {nd }}$ edition.

[21]. WHO Geneva 1996. ISBN 9241544800.

[22]. Guidelines for drinking water quality: Volume 111 Surveillance and control of community supplies, $2^{\text {nd }}$ edition.

[23]. WHO Geneva 1998. ISBN 9241545038.

[24]. Rickards A, Baetram J. Drinking water monitoring and surveillance. Africa Health, November 1993, pp.10-14.

[25]. Krikwood, A. Safe water for Africa. Africa Health, September 1998, pp. 9-13.

[26]. EUPOPEAN STANDARDS FOR DRINKING - WATER SECOND EDITION.

[27]. US Department of Health, Education and Welfare (1962) Public Health Service Drinking Water standards 1962, Washington DCCUS Public Health Service Publication (No 956).

[28]. Windle Taylor E (Thresh, Beales Suckling) (1958) The Examination of water and water supply, $7^{\text {th }}$ ed., Londan Charchil.

[29]. World Health organization (1963) international standards for - drinking water Inded, Geneva.

[30]. AFNOR (Association Franc aise de Normalisation), 1990. Eaux-me 'thodes d'essais. Recueil de Normes Franc aises, 4th edn. la De 'fense, Paris, 735 pp 